\title{
ロジックコントローラによって制御される システムの故障診断
}

\author{
正員 残間 忠直* 非会員 宮林 司** \\ 正 員 石田 宗秋*
}

Fault Diagnosis for System Controlled by Logic Controller

Tadanao Zanma*, Member, Tsukasa Miyabayashi**, Non-member, Muneaki Ishida*, Member

\begin{abstract}
This paper concerns fault diagnosis for sequential control systems controlled by logic controllers. Incompleteness of the system model is regarded as nondeterministic. The considered systems are modeled by set-valued functions. Thus, the system model has more than one transition in each state of it. We propose a state space generation algorithm of the closed loop system of the plant model and the corresponding logic controller. Then, we show that the proposed algorithm yields only expected normal operation. Finally, we apply it to fault diagnosis for sequential control systems based on an idea that a nonexistent state and/or transition is faulty.
\end{abstract}

キーワード：故障検出，故障特定，ロジックコントローラ

Keywords: fault detection, fault identification, logic controller.

\section{1. はじめに}

離散事象システム (Discrete Event System:DES) とは, 事象か離散的かつ非同期的に生起することにより状態が不 連続に変化するようなシステムの総称である ${ }^{(1)}$ 。DES に 関する制御・解析等は, 有限状態オートマトンを主とした 言語理論 ${ }^{(2)}$ を中心に，グラフ的モデル ${ }^{(3)}{ }^{(4)}$, 代数的モデ ル $^{(5)(6)}$, 論理モデル ${ }^{(7)}(8)$ 等さまざまな形式的モデルを用 いて盛んに研究されている。

DES として捉えられるシステムは, 計算機システム, 通 信ネットワークシステム, 航空機運行システム, 生産システ ムなど多岐に及ぶ。なかでも生産システムでは，あらかじめ 定められた順序に従ってプロセスを逐次進めるシーケンス 制御が産業界において広く用いられている。シーケンス制 御を実行するための代表的な機器にはプログラマブルロジッ クコントローラ (Programmable Logic Controller:PLC) があり，乥のプログラミング言語として，ラダー図 (Ladder Diagram) が挙げられる。ラダー図は信号の論理組合

\footnotetext{
* 三重大学工学部

T 514-8507 三重県津市栗真町屋町 1577

Faculty of Engineering, Mie University

1577 Kurimamachiya, Tsu, Mie 514-8507

** (株) 京三製作所

干 230-0031 神奈川県横浜市鶴見区平安町 2-29-1

Kyosan Electric Mfg. Co., Ltd.

2-29-1 Heian, Tsurumi, Yokohama, Kanagawa 230-0031
}

せを視覚的に捉えることができ，従来からのシーケンス制 御回路の知識を兴のまま活かすことができる。しかしなが ら，ラダー図には信号の組合せのみしか表現されておらず， 制御対象の状態の遷移関係が記述できていないため，仕樣 とシーケンスの対応がわかりづらいという欠点を持つ。こ のため，ラダー図によって制御される生産システムにおい て故障が生じたとき, 弚の故障の検出・特定は一般には困難 であるといえる。また, 生産システムに限らず, システム における故障は, 操作性, 生産性および安全性の低下を招 く, とりわけ, システムや人命の安全を確保する上で, 事 故の未然防止対策や故障の検出・特定・除去は, 極めて重 要な要素技術である。

DES の故障診断に関する研究として, Ozveren および Willsky らによる可観測性とフォールトトレランスの概念 の導入が挙げられる ${ }^{(9)}$ 。これは, DES の出力系列に基づい て状態を推定し，想定しない観測出力を故障とする立場で ある。また, Sampath および Sinnamohideen は, 故障事 象が組み込まれた DES モデルに対して可診断性の概念を 導入し, 診断器の構成手続きと可診断性に関する必要十分 条件を導出した ${ }^{(10)(11)}$ 。

シーケンス制御系における故障診断問題に限定すると， 藤本は制御対象モデルを離散時間多項式非線形システムの 特別な場合と捉え，一般化した離散時間多項式非線形シス テムに対する制御器および観測器の設計法を提案し, 制御 対象の異常を検出することが可能であることを示した ${ }^{(12)}$ 。 
また, 伊藤, 南里らは, ペトリネットを用いて故障許容技 術すなわちフォールトトレランスを考慮した故障診断法を 開発し，棟間台車システムモデルに適用した ${ }^{(13)}$ 。

上述の故障診断は，想定された故障があらかじめ故障事 象として組み込まれたオートマトンあるいはペトリネット などでモデル化された DES の状態推定に基づいている。し たがって，想定される故障状態を含む制御対象の完全なモ デルが必要となる。しかしながら，弚のようなモデルは一 般に得ることが困難であるばかりでなく，仮に得られたと してもモデルの状態数が多くなり，結果的にモデルが複雑 になるという問題が生じる。

そこで本稿では, 故障の状態や事象を陽に含まない DES モデルに対する故障診断問題を考察する。具体的には, PLC としてラダー図によって制御されるシーケンス制御系を例 にとり，プラントモデルの不完全性を等価的に非決定性的 に捉え , プラントモデルの状態遷移を集合值関数として表 現する。また , ラダー図とプラントモデルの閉ループ系を 構成し，状態空間および状態遷移を与えるアルゴリズムを 提案する。提案アルゴリズムによって得られる閉ループ系 の状態遷移図は，与えられた初期状態より生成し得る状態 および状態遷移であることを示し，状態遷移図から逸脱し た状態および状態遷移を故障状態とみなす。なお本稿では， リミットセンサなどのような 2 值状態のみ取り得る機器が 何らかの原因で正常に動作していない状況を故障と想定す る。次に，提案手法によって抽出された故障状態に対し，光 の状態の故障箇所を特定する手法を提案する。最後に，提 案手法を具体例に適用し，光の有効性を明らかにする。

\section{2. 準 備}

本節では，準備として，プラントモデルを定式化し，ラ ダー図の形式的表現を与える。光して，両者の閉ループ系 を構成する。

以下, $\mathbb{Z}_{+}$は 0 以上の整数の集合， $\mathbb{Q}_{+}$は 0 以上の有理数 の集合, $\mathbb{B}$ は二值変数 (ブール変数) の集合を表す。また， 任意の $b_{1}, b_{2} \in \mathbb{B}$ に対し， $\bar{b}_{1}$ は $b_{1}$ の論理否定を， $b_{1} \cdot b_{2}$ および $b_{1}+b_{2}$ は，光れ攵れ $b_{1}, b_{2}$ の論理積および論理和 を表す。

〈2. 1〉 プラントモデル＼cjkstart本研究で扱うプラントモデ ルは，

$$
\begin{aligned}
& x_{p}(k+1) \in f_{p}\left(x_{p}(k), u(k), w(k)\right) \\
& y(k)=g_{p}\left(x_{p}(k), w(k)\right) \cdots \ldots \ldots \ldots
\end{aligned}
$$

と記述されるものとする。ここで， $k \in \mathbb{Z}_{+}$は離散時間， $x_{p} \in X_{p} \subseteq \mathbb{B}^{n_{p}}, u \in U \subseteq \mathbb{B}^{m}, w \in W \subseteq \mathbb{B}^{q}$ および

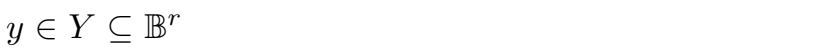
び出力である。また $, f_{p}: \mathbb{B}^{n} \times \mathbb{B}^{m} \times \mathbb{B}^{q} \rightarrow 2^{\mathbb{B}^{n}} \backslash \emptyset$ は集 合値関数とする。

〈2. 2〉 ラダー図

〈2. 2. 1〉 ラダー図の動作ＰLCの言語としてのラダー 図を，図 $1^{(19)}$ を例にとって説明する。ラダ一図とは，シー

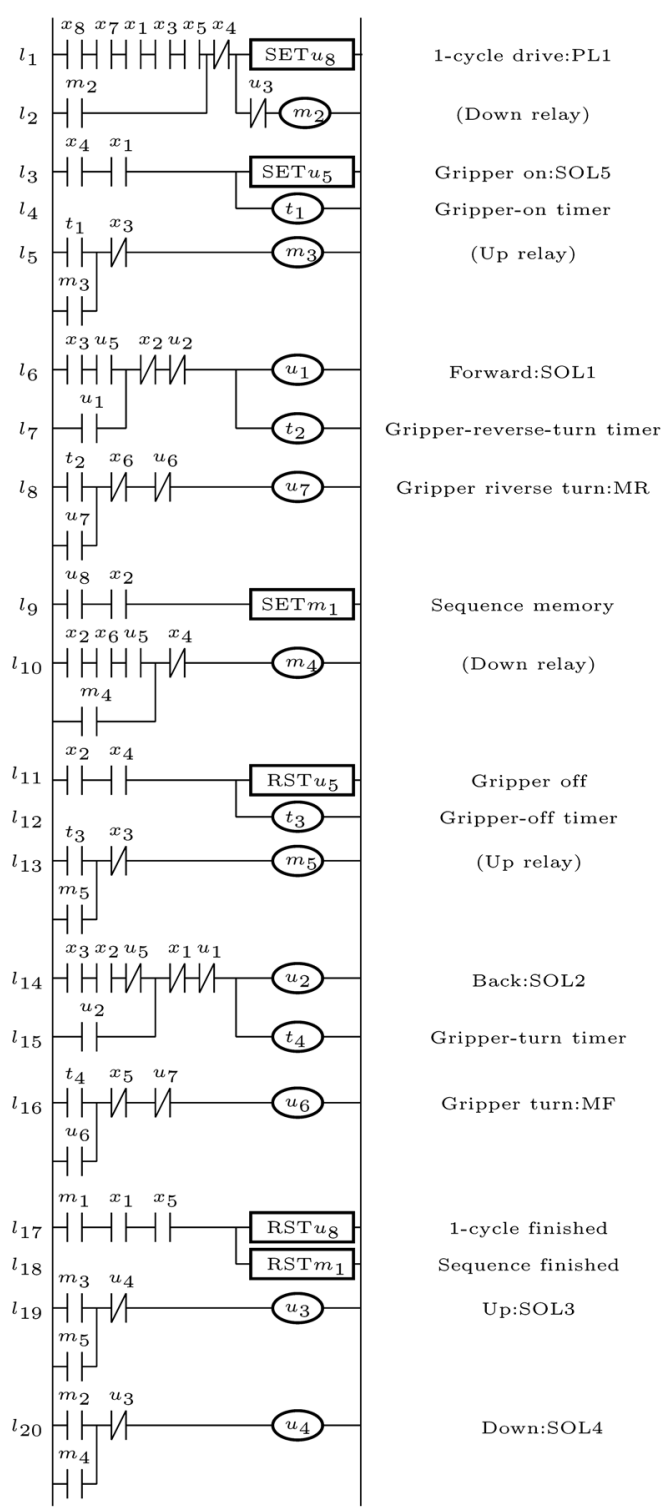

図 1 ラダー図の例

Fig. 1. Example of ladder diagram.

ケンス制御回路を構成する有接点リレーなどの制御装置を 記号化したものであり，図 1 のように信号の論理組合せを 視覚的に表した形状が梯子形であることから光のように呼 ばれる。ラダー图中の二重縦線で描かれている記号は入力 値が 1 であるときに導通することを表し，二重縦線に斜線 があるものは入力值が 0 のときに導通することを表す。前 者を $\mathrm{a}$ 接点，後者を $\mathrm{b}$ 接点という。また，長方形または円 で描かれているシンボルは出力を表している。ラダー図に おいて, 各入力と出力の組を段と呼び, ラダー図の上から 数えて第 $n$ 番目の段を $l_{n}$ と記述する。本研究ではこれ以 降, 入出力は二值変数を持つものとする。 $N$ 段からなるラ ダ一図は出力值を $l_{1}, l_{2} \ldots$ と順に $l_{N}$ まで計算 (スキャン) することによって，各段に対応している值を出力する。制 御対象は 1 回のスキャンの最終段の出力值を出力した時点 での出力値に従って動作する。ラダー図に用いられる記号 については以下のとおりである。 $\Sigma_{X}=\left\{x_{1}, x_{2}, \ldots, x_{n_{x}}\right\}$ ， 
$\Sigma_{U}=\left\{u_{1}, u_{2}, \ldots, u_{n_{u}}\right\}, \Sigma_{T}=\left\{t_{1}, t_{2}, \ldots, t_{n_{t}}\right\}$ および

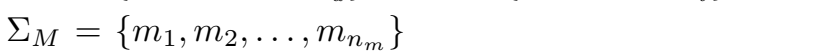
(センサ值) シンボルの有限集合, (空ではない) 入カシン ボルの集合，タイマシンボルの有限集合およびリレーおよ びメモリシンボルの有限集合である。

次に上記のシンボルで表現される機能を図 1 を用いて述 べる。

$\Sigma_{X}$ 内のシンボルは位置情報・部品の有無・起動スイッ チなど制御対象の状態を表す。

$\Sigma_{U}$ 内のシンボルは上昇・前進・回転など制御対象への 素動作を表し，セット・リセット（自己保持機能）を持た ないものと持つものに分けられる。前者を $\Sigma_{U}^{1}$ ，後者を $\Sigma_{U}^{2}$ で表すと， $\Sigma_{U}=\Sigma_{U}^{1} \cup \Sigma_{U}^{2}$ である。ここで，U்は互いに素 な結合を表す。図 1 では $\Sigma_{U}^{1}=\left\{u_{1}, u_{2}, u_{3}, u_{4}, u_{6}, u_{7}\right\}$ ， $\Sigma_{U}^{2}=\left\{u_{5}, u_{8}\right\}$ である。 $l_{3}$ において $x_{4}$ と $x_{1}$ がともにオン のときに $u_{5} \in \Sigma_{U}^{2}$ がセットされる。一旦 $u_{5}$ がセットされ ると $x_{4}$ または $x_{1}$ のうちいずれかがオフになっても $u_{5}$ は才 フとはならず, $l_{11}$ で $x_{2}$ と $x_{4}$ がともにオンとならない限り オフにはならない。一方 , $l_{6}$ の $u_{1} \in \Sigma_{U}^{1}$ は $x_{3} \cdot u_{5} \cdot \bar{x}_{2} \cdot \bar{u}_{2}$ の論理值が 1 のときオンになり一旦オンになると $x_{2} \cdot u_{2}$ の論理値が 1 であればオンとなるが , $\bar{x}_{2}$ または $\bar{u}_{2}$ のいず れかがオフになれば, $u_{1}$ はオフとなる。

$\Sigma_{T}$ 内のシンボルはタイマを表す。光れに関する入力の 条件が成立しても，対応する時間が経過するまではオンと はならない。図 1 では, $l_{4}$ において $x_{4}$ と $x_{1}$ がともにオン になれば，タイマ $t_{1}$ がオンとなる条件が成立するが，光の 後 $t_{1}$ に対応する時間 $\tau_{1}$ が経過しないと $t_{1}$ はオンしない。

$\Sigma_{M}$ 内のシンボルはラダー図の内部の入出力の值をラダー 図内て伝達する役割を果たし，弚れ自体か制御対象への動作 指令にはならない。 $\Sigma_{U}$ と同樣に， $\Sigma_{M}=\Sigma_{M}^{1} \cup \dot{U} \Sigma_{M}^{2}$ と分割 される。図 1 では $\Sigma_{M}^{1}=\left\{m_{2}, m_{3}, m_{4}, m_{5}\right\}, \Sigma_{M}^{2}=\left\{m_{1}\right\}$ である。たとえば，図 1 において， $l_{2}$ の出力 $m_{2}$ が $l_{20}$ の 入力に伝達されている。

〈2·2·2〉 ラダー図の形式的表現プラントモデル (1) および $(2)$ 式に対する $N$ 段から構成されるラダー図の形式 的表現を与えるために，いくつかの定義を与える。

セット・リセット型のシンボルに関して,$\sigma \in \Sigma_{U}^{2} \cup \Sigma_{M}^{2}$ ならば補助変数の集合として $\hat{\sigma}:=\left\{\sigma^{1}, \sigma^{0}\right\} \subseteq \mathbb{B}^{2}$ を定義 する。また，

$$
\hat{\Sigma}_{U}^{2}:=\bigcup_{\sigma \in \Sigma_{U}^{2}} \hat{\sigma}, \quad \hat{\Sigma}_{M}^{2}:=\bigcup_{\sigma \in \Sigma_{M}^{2}} \hat{\sigma} \cdots \cdots
$$

と定義する。

ラダー図の段 $l_{i}(i=1,2, \ldots, N)$ の出力部に注目す る。ラダー図に現れる出カシンボルを段の昇順に $\tilde{x}_{c}^{1} \prec$ $\tilde{x}_{c}^{2} \prec \ldots \prec \tilde{x}_{c}^{N}$ と順序づける。ここで, $\tilde{x}_{c}^{i} \in \Sigma:=$ $\Sigma_{U}^{1} \dot{\cup} \Sigma_{M}^{1} \dot{U} \hat{\Sigma}_{U}^{2} \dot{\cup} \hat{\Sigma}_{M}^{2} \dot{U} \Sigma_{T}(i=1,2, \ldots, N)$ である。さらに 表記の簡単化のため, $l_{i}$ の出カシンボル $\tilde{x}_{c}^{i}(i=1,2, \ldots, N)$ が $\sigma \in \Sigma$ であることを $\tilde{x}_{c}^{i} \sim \sigma$ と記述する。

セット・リセット型のシンボルに関して，以下を仮定する。
〔 仮定 1] $\left(\forall \sigma \in \Sigma_{U}^{2} \cup \Sigma_{M}^{2}\right) \sigma^{1} \prec \sigma^{0}$

仮定 1 では，セット・リセット型のシンボル $\sigma$ に対し， $\sigma_{1}$ がセット， $\sigma_{0}$ がリセットを表している。また，仮定 1 は， 後の説明を簡単にするためだけに必要とされ，本質的に重 要な仮定ではないことに注意されたい。

ここで, 記述の簡単化のため，いくつかの表記法を定義す る。ある実べクトル $q=\left[q_{1} q_{2} \ldots q_{m}\right]^{\prime}, \tau=\left[\tau_{1} \tau_{2} \ldots \tau_{m}\right]^{\prime}$ と $i \in\{1,2, \ldots, m\}$ およびスカラ $z$ に対し，次の表記と 3 つのオペレータを定義する。

$$
\begin{aligned}
& q_{(i: j)}:=\left[\begin{array}{lll}
q_{i} & q_{i+1} \ldots q_{j}
\end{array}\right]^{\prime} \text { for } 1 \leq i \leq j \leq m
\end{aligned}
$$

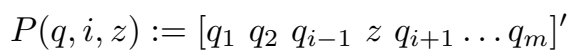

$$
\begin{aligned}
& H(q, z)_{i}:= \begin{cases}q_{i}+z & \text { if } q_{i} \geq 0 \\
q_{i} & \text { otherwise }\end{cases} \\
& G(q, \tau)_{i}:= \begin{cases}0 & \text { if } q_{i}<\tau_{i} \\
1 & \text { otherwise }\end{cases}
\end{aligned}
$$

ここで, オペレータ $G$ は後述するラダー図の状態更新則に用 いられる。たとえば， $\tau=[34]^{\prime}$ を定べクトルとする。いま， $q=\left[\begin{array}{ll}2 & 3\end{array}\right]^{\prime}$ とすると,$G(q, \tau)=[0,0]^{\prime}$ となる。このように才 ペレータ $G$ は, ラダー図のタイマの状態があらかじめ定めら れた時刻に達しない限りはオンとならないことを表すために 用いられる。また，あるべクトル $q=\left[q_{1} q_{2} \ldots q_{n_{u}+n_{m}+n_{t}}\right]^{\prime}$ に対して， $q_{J_{U}}, q_{J_{M}}$ および $q_{J_{T}}$ を光れ光れ， $q$ の 1 番目か ら $n_{u}$ 番目まで, $n_{u}+1$ 番目から $n_{u}+n_{m}$ 番目までおよび $n_{u}+n_{m}+1$ 番目から $n_{u}+n_{m}+n_{t}$ 番目までの成分からな るべクトルを表すものとする。ただし,$\Sigma_{M}=\emptyset\left(\Sigma_{T}=\emptyset\right)$ のときは $J_{M}\left(J_{T}\right)$ は未定義とする。これらの表記を用い て, ラダー図の状態を $x_{c}:=\left[x_{c_{J_{U}}}{ }^{\prime} x_{c_{J_{M}}{ }^{\prime}} x_{c_{J_{T}}{ }^{\prime}}\right]^{\prime}$ と定義す る。ただし $, x_{c J_{U}} \in \mathbb{B}^{n_{u}}, x_{c J_{M}} \in \mathbb{B}^{n_{m}}, x_{c J_{T}} \in \mathbb{Q}^{n_{t}}$ と する。さらに，ラダー図のスキャンを考慮するために，補 助状態を $\hat{x}_{c}=\left[\begin{array}{lll}\hat{x}_{c_{J_{U}}}^{\prime} & \hat{x}_{c_{J_{M}}}^{\prime} & \hat{x}_{c_{J_{T}}}^{\prime}\end{array}\right]^{\prime}$ と定義する。ただし， $\hat{x}_{c_{J_{U}}} \in \mathbb{B}^{n_{u}}, \hat{x}_{c_{J_{M}}} \in \mathbb{B}^{n_{m}}, \hat{x}_{c_{J_{T}}} \in \mathbb{Q}^{n_{t}}$ とする。

$\hat{x}_{c}$ および $\tau=\left[\begin{array}{lll}\tau_{1} & \tau_{2} \ldots \tau_{n_{t}}\end{array}\right]^{\prime}$ ただし， $\tau_{i} \in \mathbb{Q}_{+}$ $\left(i=1,2, \ldots, n_{t}\right)$ に関して, 補助関数 $\hat{g}\left(\hat{x}_{c}, \tau\right):=$ $\left[\hat{x}_{c_{J_{U}}}^{\prime} \hat{x}_{c_{J_{M}}}^{\prime} G\left(\hat{x}_{c_{J_{T}}}, \tau\right)^{\prime}\right]^{\prime}$ を定義する。

ラダー图の $l_{i}(i=1,2, \ldots, N)$ に注目する。 $l_{i}$ を論 理関数と捉えると, $l_{i}: \mathbb{B}^{n_{c}} \times \mathbb{B}^{r} \rightarrow \mathbb{B}$ ，ただし $n_{c}:=$ $n_{u}+n_{m}+n_{t}$ と書ける。ラダー図の $k+1\left(k \in \mathbb{Z}_{+}\right)$回目 の $i(i=1,2, \ldots, N)$ 段目までのスキャン時のラダー図の 状態を $\hat{x}_{c}\left(k+\frac{i}{N}\right)$ と記述する。このとき, $k+1$ 回目の $i$ 段目のラダー图の出力值は, $\hat{x}_{c}\left(k+\frac{i-1}{N}\right)$ および $y(k)$ を用 いて,$l_{i}\left(\hat{g}_{c}\left(\hat{x}_{c}\left(k+\frac{i-1}{N}\right), \tau\right), y(k)\right)$ と記述できる。 $b \in \mathbb{B}$ に 対して, $l_{i}\left(\hat{g}_{c}\left(\hat{x}\left(k+\frac{i-1}{N}\right), \tau\right), y(k)\right)=b$ であることを, $N$ と $\tau$ は固定されているので, 記述の簡単化のため論理命題 $p_{i, k, y}=b$ と記述する。

以上の表記を用いて , ラダー図の状態更新則を再帰的に 記述する。はじめに， $x_{c}(0)$ をラダー図の初期状態とする。 また, $k\left(k \in \mathbb{Z}_{+}\right)$回目のラダー図のスキャン終了後のラ 
ダー図の状態を $x_{c}(k)$ とする。このとき， $x_{c}(k)$ を用いて， $\hat{x}_{c}\left(k+\frac{i}{N}\right)(i=0,1,2, \ldots, N)$ を次のように再帰的に定義 する。

$$
\hat{x}_{c}\left(k+\frac{i}{N}\right):= \begin{cases}x_{c}(k) & i=0 \\ f_{c}^{i}\left(\hat{x}_{c}\left(k+\frac{i-1}{N}\right), y(k)\right) & \end{cases}
$$

ここで,

$$
\begin{aligned}
f_{c}^{i}\left(\hat{x}_{c}, y\right)_{J_{U}} & :=\left\{\begin{aligned}
P\left(\hat{x}_{c}, j, b\right)_{J_{U}} & \text { if }\left[p_{U}\right] \\
\hat{x}_{c_{J_{U}}} & \ldots \ldots \ldots \ldots \ldots \ldots
\end{aligned}\right. \\
f_{c}^{i}\left(\hat{x}_{c}, y\right)_{J_{M}} & := \begin{cases}P\left(\hat{x}_{c}, j, b\right)_{J_{M}} & \text { if }\left[p_{M}\right] \\
\hat{x}_{c_{J_{M}}}, \ldots \ldots \ldots \ldots \ldots\end{cases} \\
f_{c}^{i}\left(\hat{x}_{c}, y\right)_{J_{T}} & :=\left\{\begin{aligned}
P\left(H\left(\hat{x}_{c_{J_{T}}}, \Delta\right), j, 0\right) & \text { if }\left[p_{T}\right] \\
H\left(\hat{x}_{c_{J_{T}}}, \Delta\right) & \text { otherwise }
\end{aligned}\right.
\end{aligned}
$$

であり，

$$
\begin{aligned}
{\left[p_{U}\right] \leftrightarrow } & \left(\left[\tilde{x}_{c}^{i} \sim y_{j}\right] \wedge\left[p_{i, k, y}=1\right]\right) \\
& \vee\left(\left[\tilde{x}_{c}^{i} \sim y_{j}^{b}\right] \wedge\left[p_{i, k, y}=b\right]\right) \\
{\left[p_{M}\right] \leftrightarrow } & \left(\left[\tilde{x}_{c}^{i} \sim m_{j}\right] \wedge\left[p_{i, k, y}=1\right]\right) \\
& \vee\left(\left[\tilde{x}_{c}^{i} \sim m_{j}^{b}\right] \wedge\left[p_{i, k, y}=b\right]\right) \\
{\left[p_{T}\right] \leftrightarrow } & {\left[\tilde{x}_{c}^{i} \sim t_{j}\right] \wedge\left[\hat{x}_{c_{J_{T}} j}<0\right] \wedge\left[p_{i, k, y}=1\right] }
\end{aligned}
$$

である。ただじ， $\Delta \in \mathbb{Q}+$ は時間経過を表す。ラダ一図の $k+1\left(k \in \mathbb{Z}_{+}\right)$回目の $N$ 段目スキャン終了後の状態は, 補 助状態を用いて,

$$
x_{c}(k+1):=\hat{x}_{c}\left(k+\frac{N}{N}\right)=\hat{x}_{c}(k+1) .
$$

とする。以上より，プラントモデル (1) および (2) 式に対 するラダー図の状態の更新則は，

$$
\begin{aligned}
x_{c}(k+1) & =\hat{x}_{c}(k+1) \\
& =f_{c}^{N}\left(\hat{x}_{c}\left(k+\frac{N-1}{N}\right), y(k)\right) \\
& =f_{c}^{N}\left(f_{c}^{N-1}\left(\hat{x}_{c}\left(k+\frac{N-2}{N}\right), y(k)\right), y(k)\right) \\
& \vdots \\
& =f_{c}^{N}\left(f_{c}^{N-1} \ldots\left(f_{c}^{1}\left(\hat{x}_{c}(k), y(k)\right), y(k)\right) \ldots y(k)\right) \\
& =f_{c}^{N}\left(f_{c}^{N-1} \ldots\left(f_{c}^{1}\left(x_{c}(k), y(k)\right), y(k)\right) \ldots y(k)\right)
\end{aligned}
$$

と記述できる。(9) 式より，プラントモデル (1) および $(2)$ 式に対するラダ一図は適切な $f_{c}: \mathbb{B}^{n_{c}} \times \mathbb{B}^{r} \rightarrow \mathbb{B}^{n_{c}}$ を用 いて ,

$$
\begin{aligned}
& x_{c}(k+1)=f_{c}\left(x_{c}(k), y(k)\right) \ldots \ldots \ldots \ldots \ldots \\
& u(k)=g_{c}\left(x_{c}(k)\right)=\left[\begin{array}{lll}
I_{n_{u}} & O_{n_{u} \times n_{m}} & O_{n_{u} \times n_{t}}
\end{array}\right] x_{c}(k)
\end{aligned}
$$

と記述できる。ここで， $I_{n_{u}}$ は $n_{u}$ 次の単位行列であり， $O_{n_{u} \times n_{m}}$ および $O_{n_{u} \times n_{t}}$ は, 弚れ光れ $n_{u} \times n_{m}$ および $n_{u} \times n_{t}$ の零行列を表す。なお， $n_{u}, n_{m}$ および $n_{t}$ は， 乥れ攵れ, 入力シンボルの有限集合の要素数, リレーおよ びメモシンボルの有限集合の要素数およびタイマシンボル の有限集合の要素数であることに注意されたい。

〈2: 3〉 閉ループシステムの構成 前節までに得られた プラントモデル $(1)$ および (2) 式と炎のラダー図 (10) および (11) 式から構成される閉ループ系の状態変数を $x:=\left[x_{p}^{\prime} x_{c}^{\prime}\right]^{\prime}$ とすると，閉ループ系は，

$$
\begin{aligned}
& x(k+1) \in f(x(k), w(k)) . \\
& y(k)=g(x(k)) \cdots \ldots . .
\end{aligned}
$$

と非決定性を有するシステムとして記述できる。

なお，制御対象への外部入力 $w \in \mathbb{B}^{q}$ は， “起動スイッチ が押される”という事象や “部品が置かれる”という事象の ように，ラダー図による動作指令では実現できない事象を 表現する入力である。

\section{3. 状態空間抽出アルゴリズムと故障診断}

本節では, プラントモデルと炎のラダー図から構成され る閉ループ系の状態空間を抽出するアルゴリズムを提案す る。次に, 得られた状態空間に存在しない状態および状態 遷移により生起されない状態は与えられた初期状態から生 成されないことから故障状態であるとみなし, 故障診断手 法を提案する。

$\langle 3 \cdot 1\rangle$ 状態空間抽出

〈 3. 1· 1〉 ラダー図の状態空間 ラダー図 (10)および (11) 式によって与えられるラダー図の取り得る状態は, ラ ダー図の初期状態とプラントモデルの出力空間によって制 限される。光こで, 閉ループ系の状態空間を考慮する前に， ラダー図の状態空間 $X_{c}$ を与える。ラダー図の状態空間を 抽出することにより, ラダー図によって生起しない状態を 削除することができる。ラダー図の取り得る状態空間を抽 出するアルゴリズムを Algorithm1 に示す。なお，アルゴ リズム中の注釈部は後の説明にて引用する。

[Algorithm1] ラダー図の状態空間 $X_{c}$

Step 1 (Initialization)

data $L \subseteq \mathbb{B}^{n_{c}}, Y \subseteq \mathbb{B}^{r}$

output $X_{c}$;

$k:=0$;

$L_{0}:=L$;

Step 2 (Successor)

$L_{k+1}:=L_{k}$;

for $x_{c} \in L_{k}$ do 


$$
\begin{aligned}
& \text { for } y \in Y \text { do } \\
& x^{*}:=f_{c}\left(x_{c}, y\right) ;^{(1-2-1)} \\
& L_{k+1}:=L_{k+1} \cup\left\{x^{*}\right\} ;^{(1-2-2)}
\end{aligned}
$$

end for

end for

Step 3 (Termination)

$$
\text { if } \begin{aligned}
& L_{k+1}=L_{k} \text { then } \\
& X_{c}:=L_{k} ; \\
& \text { STOP; }(1-3-1)
\end{aligned}
$$

else

$$
\begin{aligned}
& k:=k+1 \\
& \text { GO TO Step } 2 ;^{(1-3-2)}
\end{aligned}
$$

end if

end

Algorithm1 について以下に説明する。

Step 1 (Initialization) では, 初期状態の単集合 $L_{0}$ を 与える。

Step 2 (Successor) では, ラダー図の取り得る状態を新 たに抽出し , ラダー図の状態空間を拡張する。ラダー図の 状態集合 $L_{k}$ に含まれる各状態とプラントモデルの出力と の関数から新たなラダー図の状態を抽出し (注釈 $\left.{ }^{(1-2-1)}\right)$, ラダー図の状態集合に加え, 新たなラダー図の状態集合を 得る(注釈 $(1-2-2)$ )。

Step 3 (Termination) では, Algorithm1 の終了条件， つまり，ラダー図の状態空間抽出終了条件を与える（注釈 $\left.{ }^{(1-3-1)}\right)$ 。終了条件を満たさないときはStep 2 から繰り返 し実行する (注釈 $\left.{ }^{(1-3-2)}\right)$ 。本ステップは,$L_{k} \neq L_{k+1}$ で ある限り，繰り返し実行されることに注意されたい。

また，Algorithm1に対し，以下の補題が成立する。

〔補題 1]Algorithm1 において， $L_{k^{*}+1}=L_{k^{*}}$ となる $k^{*}<\infty$ が存在し，炎のときAlgorithm1 は終了する。

[証明] 全ての $k \in \mathbb{Z}_{+}$に対し, $L_{k} \subset L_{k+1} \subseteq \mathbb{B}^{n_{c}}$ と仮 定する。このとき, $k$ は単調増加するので, ある $\tilde{k}<\infty$ が存在し， $\mathbb{B}^{n_{c}} \subset L_{\tilde{k}}$ となり，仮定に矛盾する。

〈 3. 1· 2〉 閉ループ系の状態空間と状態遷移 Algorithm1 によってラダー図の状態空間 $X_{c}$ が得られた後 , (12) およ び (13) 式で与えられる閉ループ系の状態空間および状態 遷移を抽出するアルゴリズムを Algorithm2 に示す。なお， アルゴリズム中の注釈部は後の説明にて引用する。

\section{[Algorithm2] 閉ループ系の状態空間 $X$}

$$
\begin{aligned}
& \text { Step } 1 \text { (Initialization) } \\
& \text { data } x_{p} \in \mathbb{B}^{n}, x_{c} \in X \\
& \text { output } X ; \\
& k:=0 \\
& X_{0}:=\left\{\left[x_{p}^{\prime} x_{c}^{\prime}\right]^{\prime}\right\} \\
& X_{0}^{\dagger}:=X_{0} ;
\end{aligned}
$$

data $x_{p} \in \mathbb{B}^{n}, x_{c} \in X_{c}, W \subseteq \mathbb{B}^{q}$;

Step 2 (Successor)

$$
\begin{aligned}
& X_{k+1}:=X_{k} ; \\
& \text { for } x^{\dagger} \in X_{k}^{\dagger} \text { do }
\end{aligned}
$$

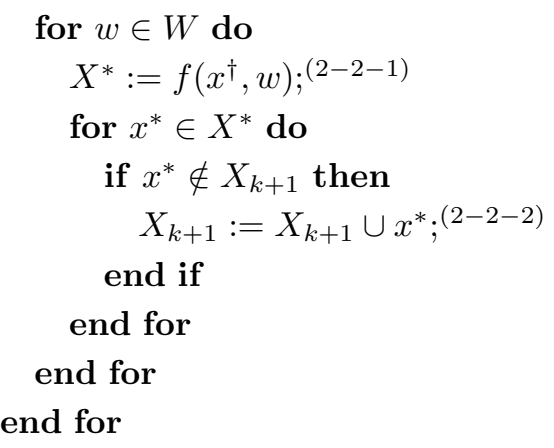

Step 3 (Termination)

if $X_{k+1}=X_{k}$ then

$X:=X_{k}$ STOP; ${ }^{(2-3-1)}$

else

$$
\begin{aligned}
& X_{k+1}^{\dagger}:=X_{k+1} \backslash X_{k} ; \\
& k:=k+1 ; \\
& \text { G0 TO Step } 2 ;^{(2-3-2)}
\end{aligned}
$$

end if

end

Algorithm2 について以下に説明する。

Step 1 (Initialization) では, 閉ループ系の初期状態の単 集合 $X_{0}$ を与える。

Step 2 (Successor) では, 閉ループ系の取り得る状態を 新たに抽出し, 閉ループ系の状態空間を拡張する。抽出さ れた閉ループ系の状態空間 $X_{k}^{\dagger}$ の各状態 $x^{\dagger}$ から遷移先の状 態集合 $X^{*}$ を抽出する (注釈 $\left.{ }^{(2-2-1)}\right) 。 x^{*} \in X^{*}$ が新たに 抽出された状態であれば, 弚れを状態空間 $X_{k+1}$ に加える (注釈 $\left.{ }^{(2-2-2)}\right)$ 。一方,$x^{*} \in X^{*}$ か既に $X_{k+1}$ 内に存在し
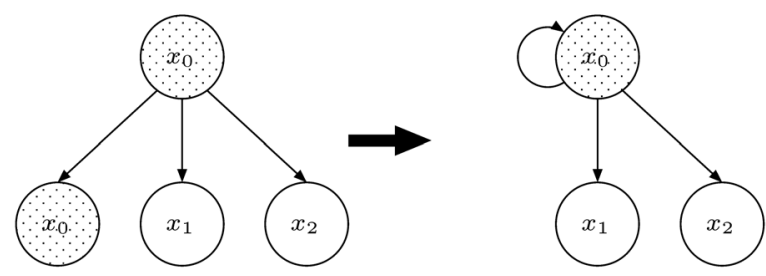

図 2 遷移先の変更兴の 1

Fig. 2. Modification of transition \#1.

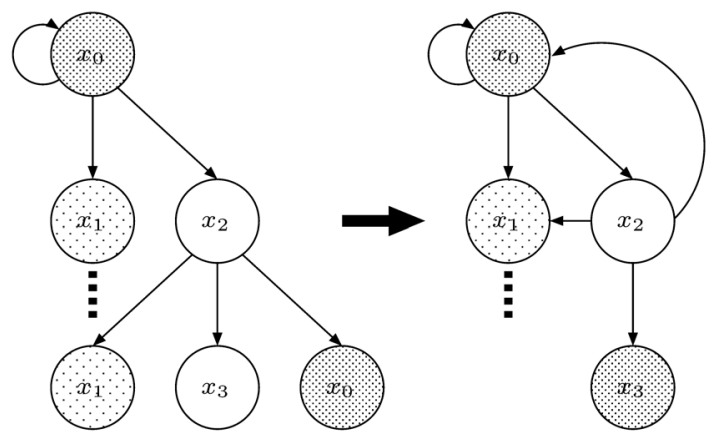

図 3 遷移先の変更光の 2

Fig. 3. Modification of transition \#2. 
てれば, 遷移は关の状態に適切に変更される。光のような 場合の例として，図 2 および図 3 を用いて説明する。図 2 に示すように, $f\left(x_{0}, w\right)=\left\{x_{0}, x_{1}, x_{2}\right\}$ が得られたとき， $x_{0}$ が重複して抽出されている (図 2 左図の網掛けの状態)。 このとき， $x_{0}$ から $x_{0}$ への遷移は図 2 右図のように変更さ れる。また，図 3 に示すように, $f\left(x_{2}, w\right)=\left\{x_{0}, x_{1}, x_{3}\right\}$ が得られたとき, $x_{0}$ および $x_{1}$ が重複して抽出されている (図 3 左図の網掛けの状態)。このとき, $x_{2}$ から $x_{0}, x_{2}$ か ら $x_{1}$ への遷移は光れ光れ図 3 右図のように変更される。

Step 3 (Termination) では, Algorithm2の終了条件 ,つ まり，閉ループ系の状態空間抽出終了条件を与える (注釈 $(2-3-1)) 。$ 終了条件を満たさないときはStep 2 から繰り返 し実行する (注釈 ${ }^{(2-3-2)}$ )。本ステップは,$X_{k+1} \neq X_{k}$ である限り，繰り返し実行されることに注意されたい。

〔補題 2〕Algorithm2 において, $X_{k^{*}+1}=X_{k^{*}}$ となる $k^{*}<\infty$ が存在し，少のとき Algorithm2 は終了する。

〔証明] 全ての $k \in \mathbb{Z}_{+}$に対し,$X_{k} \subset X_{k+1} \subseteq X_{p} \times X_{c}$ と仮定する。このとき， $k$ は単調増加するので，ある $\tilde{k}<\infty$ が存在し， $X_{p} \times X_{c} \subset X_{\tilde{k}}$ となり，仮定に矛 盾する。

Algorithm1 および Algorithm2 について次の定理を 得る。

〔定理 1] 与えられた $x_{p} \in X_{p}$ および $x_{c} \in X_{c}$ とラダー図 の状態空間 $X_{c}$ を与える Algorithm1 および Algorithm2 を用いて得られた $X$ に対して,$x \in \mathbb{B}^{n_{p}+n_{c}}$ カ閉ループ 系の状態 $\left[x_{p}^{\prime} x_{c}^{\prime}\right]^{\prime}$ から到達可能な状態であるための必要 十分条件は $x \in X$ である。

〔 証明〕 $\quad(\Rightarrow) x \in \mathbb{B}^{n_{p}+n_{c}}$ を, Algorithm1 および Algorithm2 では生成されないが $\left[x_{p}^{\prime} x_{c}^{\prime}\right]^{\prime}$ から到達可能な状 態であると仮定する。このとき,$x \in\left\{x \mid f\left(x_{\alpha}, w\right), w \in\right.$ $W\}$ である $x_{\alpha}$ が存在する。また，ある $k$ が存在し， $x_{\alpha} \in X_{k}$ とすると $x \in X_{k+1}$ となるので, 全ての $k$ に対して,$x_{\alpha} \notin X_{k}$ でなくてはならない。同樣に $x$ に到 達可能な任意の状態 $x_{\beta}$ に対して, $x_{\beta} \notin X_{k}\left(k \leq k^{*}\right)$ で なくてはならない。これは, $\left[x_{p}^{\prime} x_{c}^{\prime}\right]^{\prime} \in X_{k}$ であることに 矛盾する。

$(\Leftarrow) x$ が Algorithm1 および Algorithm2 で生成さ れれば， $x \in X$ は明らか。

〈3. 2〉 故障診断 与えられた初期状態に対して Algorithm1 およびAlgorithm2 により生成し得る状態空間お よび状態遷移に基づき，閉ループ系の故障診断手法を提案 する。

定理 1 より， $x_{f} \notin X$ となるような $x_{f}$ は，与えられた 閉ループ系の初期状態から生成されないことがわかる。し たがって，閉ループ系において，状態 $x_{f} \notin X$ が観測され たとき, $x_{f}$ は正常な状態ではない，すなわち故障状態であ るとみなすことができる。また，閉ループ系において存在 しない状態遷移により得られる状態 $x_{f} \in X$ も故障状態と みなすことができる。

乥こで，まず，本稿における閉ループ系の故障状態を以

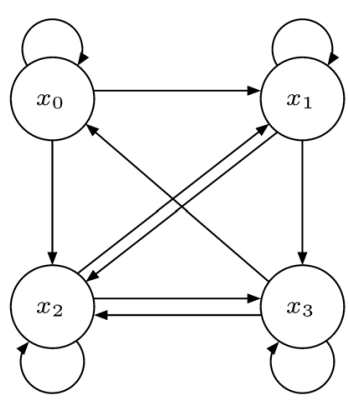

图 4 閉ループ系の状態空間 $X$ の例

Fig. 4. Example of state space of closed loop system, $X$.

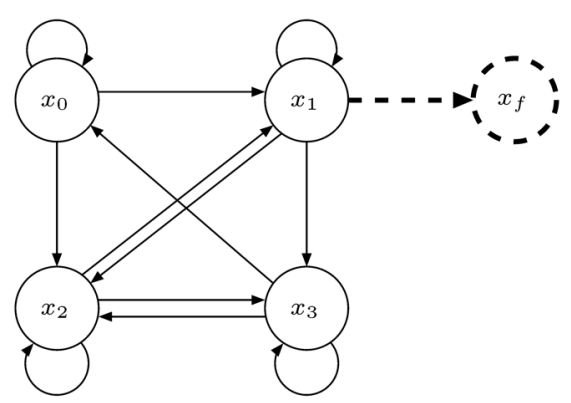

图 5 故障状態の例（存在しない状態）

Fig. 5. Example of fault state (nonexsitent state).

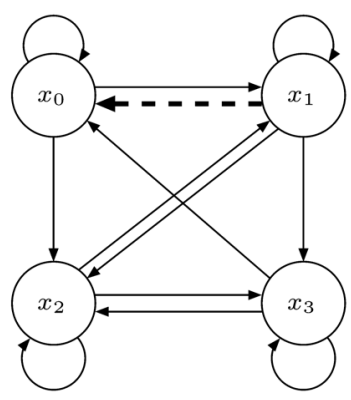

图 6 故障状態の例 (存在しない状態遷移)

Fig. 6. Example of fault state (nonexsitent transition).

下のように定義する。

〔 定義 1〕閉ループ系 (12) および (13) 式に対して，以下 のいずれかのとき $x_{f}$ を故障状態という。

(1) $x_{f} \notin X$ 。

(2) $x_{f} \in X$ かつ $(\nexists x) x_{f}=f(x, w)$ 。

图 4 に示す閉ループ系の状態遷移図を用いて，故障状 態の一例を示す。図 4 において, 閉ループ系の状態空間 は $X=\left\{x_{0}, x_{1}, x_{2}, x_{3}\right\}$ であるが，図 5 に示すような状態 $x_{f} \notin X$ が観測されたとき，閉ループ系の状態空間に存在 しない状態 $x_{f}$ は故障状態である。また , 図 6 に示すように 图 4 の閉ループ系に存在しない状態遷移により状態 $x_{0} \in X$ が観測されたとき，この遷移により観測された状態 $x_{0}$ は 故障状態である。

ここで, 以下の仮定を与える。

〔 仮定 2〕閉ループ系 (12) および (13) 式に対して， 
（1）状態および状態遷移はすべて可観測とする。

（2）プラントモデルの状態，すなわち $x_{p}$ が何らか の不具合によって正常に動作していない状況のみ を考え , プラントモデルへの入力 , すなわち $u$ は ラダー図の動作指令に従って正常に動作している ものとする。

仮定 2 の（2）より，以下ではプラントモデルの状態，た とえばリミットセンサなどの破損・動作不良などに起因す る誤動作のみを想定する。

さて，以下では故障状態 $x_{f}$ に対し， $x_{f i}\left(i=1, \ldots, n_{p}\right)$ の要素に着目し , 故障箇所の特定手法について述べる。

故障箇所の特定にあたり，故障箇所の可特定性を定義す る。ここで, 故障状態 $x_{f}$ の要素 $x_{f i}\left(i=1, \ldots, n_{p}\right)$ ，に 対して，以下のように可特定性を定義する。

〔定義 2〕故障状態 $x_{f}$ の要素 $x_{f i}\left(i=1, \ldots, n_{p}\right)$ が, 直 前に観測された状態 $x$ から遷移可能な全ての状態の $i$ 番目 の要素と異なっていれば, $x_{f}$ の要素 $x_{f i}\left(i=1, \ldots, n_{p}\right)$ は, $\left(x, x_{f}\right)_{i}$-可特定 $\left(i=1, \ldots, n_{p}\right)$ であるという。

定義 2 の可特定性は, 故障状態の $i$ 番目の要素が, 故障 状態が観測される直前の状態から生起可能な全ての状態の $i$ 番目の要素と異なることをいう。

後の表記を簡単にするために, 次の記述を導入する。

$$
\begin{aligned}
& X^{N}(x):=\left\{x^{*} \mid x^{*}=f(x, w), w \in W\right\} \cdots \cdots \\
& F\left(x, x_{f}\right):= \\
& \quad\left[x_{\left(1: n_{p}\right)}^{N_{1}} \oplus x_{f\left(1: n_{p}\right)} \ldots x_{\left(1: n_{p}\right)}^{N_{\mid X^{N}}(x) \mid} \oplus x_{f\left(1: n_{p}\right)}\right]
\end{aligned}
$$

ここで, $x^{N_{j}} \in X^{N}(x)\left(j=1, \ldots,\left|X^{N}(x)\right|\right)$ である。ま た $x_{f\left(1: n_{p}\right)}$ は，仮定 2 より，プラントモデルの状態にのみ 故障が生じることを反映しているが, 以降単に $x_{f}$ と記述 する。

以上の表記を用いて, $\left(x, x_{f}\right)_{i}$-可特定 $\left(i=1, \ldots, n_{p}\right)$ に 関して次の定理を得る。

〔 定理 2〕故障状態 $x_{f}$ と故障状態の直前の状態 $x \in X$ に 対し, $F\left(x, x_{f}\right)$ の成分 $f_{i j}$ に関して $\forall j\left(f_{i j}=1\right)(i=$ $\left.1, \ldots, n_{p}\right)$ であれば， $\left(x, x_{f}\right)_{i}$-可特定 $\left(i=1, \ldots, n_{p}\right)$ で ある。

〔 証明】 $\left(x, x_{f}\right)_{i}$-可特定 $\left(i=1, \ldots, n_{p}\right)$ でないならば， $i\left(i=1, \ldots, n_{p}\right)$ に対し,$\forall j\left(f_{i j}=1\right)$ が成立しないこ とを示す。

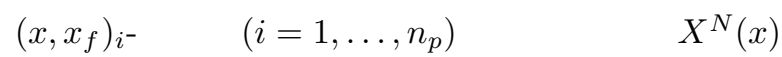
の要素の $i$ 番目の成分が $x_{f i}$ と等しい状態が存在する。 そのような状態を一般性を失うことなく $x^{N_{1}}$ とすれば， $f_{i 1}=x_{i}^{N_{1}} \oplus x_{f i}=0$ となる。したがって,$\forall j\left(f_{i j}=1\right)$ が成立しない。

\section{4. 例 題}

本節では, 前節までの提案法を具体例に適用し，㒷の有 効性を検証する。

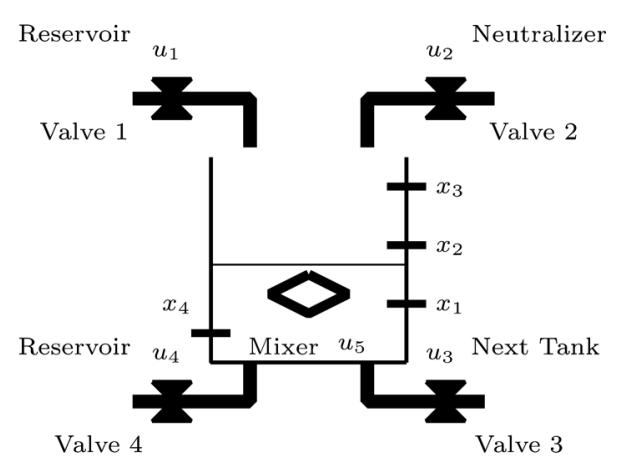

図 7 中和タンクシステム

Fig. 7. Neutralization tank system.

〈4 1〉プラントモデル 具体例として, 図 7 に示す 4 つのセンサ , 4 つのバルブおよび夜体を䚓拌する 1 つの ミキサからなる中和タンクシステムを考える。以下，対応 するシンボルの集合は, $\Sigma_{X}=\left\{x_{1}, x_{2}, x_{3}, x_{4}, x_{5}\right\}$ および $\Sigma_{U}=\left\{u_{1}, u_{2}, u_{3}, u_{4}, u_{5}\right\}$ である。ここで, $x_{i}(i=1,2,3)$ は, タンクの水位を測定する離散的なセンサ $i$ を表してお り，センサ $i$ の位置より液面が高い(低い) 場合にオン (才 フ) となる。 $x_{4}$ は, タンク内の液体の $\mathrm{pH}$ を測定するセン サを表しており，規定の $\mathrm{pH}$ 值に達したら（達しなかった ら) オン (オフ) となる。また , $x_{5}$ は起動スイッチの状態 を表しており，起動スイッチが押されているとき(押されて (ないとき) オン (オフ) となる。一方 , $u_{i}(i=1,2,3,4)$ はバルブ $i$ へ動作指令を表し, バルブ $i$ を開く (閉じる) ときオン (オフ) となる。 $u_{5}$ は䚓拌ミキサへの動作指令を 表し, 䚓拌ミキサを回転 (停止) させるときオン (オフ) と なる。以下，任意の $\sigma \in \Sigma_{X} \cup \Sigma_{U}$ に対して， $\sigma$ で示され るシンボルがオン (オフ) であることを $\sigma=1(\sigma=0)$ で 表し， 1 または 0 が一意に決定できないことを, 記号 *で 表すものとする。

图 7 の制御対象に関して , 以下の仮定を与える。

〔 仮定 3]图 7 の制御対象に関して, オンである上部のバ ルブ (バルブ 1,2$)$ の数および下部のバルブ (バルブ 3 ,

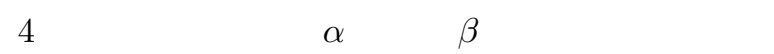

(1) $\alpha \neq 0$ かつ $\alpha \geq \beta$ のとき，液面は上昇する。

(2) $\beta \neq 0$ かつ $\alpha<\beta$ のとき, 液面は下降する。

(3) $\alpha=\beta=0$ のとき, 液面は変化しない。

仮定 3 では, 図 7 の上部のバルブ一箇所からの流量は下 部のバルブ一箇所からの流量よりも多いこと，下部のバル ブ二箇所からの流量は上部のバルブ一箇所からの流量より も多いことを示している。

プラントモデルの状態を $x_{p}:=\left[x_{1} x_{2} x_{3} x_{4}\right]^{\prime} \in \mathbb{B}^{4}$ とし， プラントモデルの状態空間 $X_{p} \subseteq \mathbb{B}^{4}$ を考える。ある液面測 定センサがオンとなっているとき，センサが正常であれば， 兴のセンサより低位置に設置された液面測定センサはオン となる。液面測定センサを低位置から $x_{1}, x_{2}$ および $x_{3}$ の 順て設置されているとき，センサの位置に関して，" $x_{2}$ が1 ならば $x_{1}$ が 1 である”および “ $x_{3}$ が 1 ならば $x_{2}$ が 1 であ 
る”という論理的条件が得られる。これにより，プラント モデルの状態空間 $X_{p}$ は $X_{p}:=\mathbb{B}^{4} \backslash\left\{[01 * *]^{\prime},[* 01 *]^{\prime}\right\}$ となる。

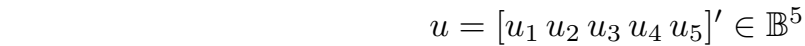
とし，プラントモデルの状態更新則および出力方程式を 考える。たとえば，任意の $k \in \mathbb{Z}_{+}$において， $x_{p}(k)=$ $[000 *]^{\prime}$ とし，バルブ 1 または 2 のいずれか一方がオン で, バルブ 3 および 4 がオンではない場合を考える。こ のとき，仮定 3 より液面は上昇するので， $x_{p}(k+1) \in$ $\left\{\left[\begin{array}{lll}0 & 0 & 0\end{array}\right]^{\prime},\left[\begin{array}{llll}1 & 0 & 0 & x_{p 4}(k)\end{array}\right]^{\prime}\right\}$ となる。同樣にして , 図 7 のプ ラントモデルは , 任意の $k \in \mathbb{Z}^{+}$に対して ，

$$
\begin{aligned}
& x_{p}(k+1) \in f_{p}\left(x_{p}(k), u(k), w(k)\right):= \\
& \left\{\left[\begin{array}{llll}
0 & 0 & 0 & *
\end{array}\right]^{\prime},\left[\begin{array}{llll}
1 & 0 & 0 & x_{p 4}(k)
\end{array}\right]^{\prime}\right\} \\
& \text { if }\left[x_{p}(k) \in\left\{\left[\begin{array}{lll}
0 & 0 & 0 *
\end{array}\right]^{\prime}\right\}\right] \wedge\left[p_{1}\right] \\
& \left\{\left[\begin{array}{llll}
1 & 0 & 0 & *
\end{array}\right]^{\prime},\left[\begin{array}{llll}
1 & 1 & 0 & x_{p 4}(k)
\end{array}\right]^{\prime}\right\} \\
& \text { if }\left[x_{p}(k) \in\left\{\left[\begin{array}{lll}
1 & 0 & 0 *
\end{array}\right]^{\prime}\right\}\right] \wedge\left[p_{1}\right]
\end{aligned}
$$

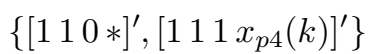

$$
\begin{aligned}
& \text { if }\left[x _ { p } ( k ) \in \left\{\left[\begin{array}{lll}
1 & \left.0 *]^{\prime}\right\}
\end{array}\right] \wedge\left[p_{1}\right]\right.\right. \\
& \left.\left\{\begin{array}{lll}
1 & 1 & 0
\end{array}\right]^{\prime},\left[\begin{array}{llll}
1 & 1 & 1 & \left.x_{p 4}(k)\right)
\end{array}\right]^{\prime}\right\} \\
& \text { if }\left[x_{p}(k) \in\left\{[111 *]^{\prime}\right\}\right] \wedge\left[p_{2}\right] \\
& \left\{\left[\begin{array}{llll}
1 & 0 & 0 & *
\end{array}\right]^{\prime},\left[\begin{array}{lllll}
1 & 1 & 0 & x_{p 4}(k)
\end{array}\right]^{\prime}\right\} \\
& \text { if }\left[x _ { p } ( k ) \in \left\{\left[\begin{array}{lll}
1 & 0 *]^{\prime}
\end{array}\right] \wedge\left[p_{2}\right]\right.\right. \\
& \left\{\left[\begin{array}{llll}
0 & 0 & 0 & *
\end{array}\right]^{\prime},\left[\begin{array}{lllll}
1 & 0 & 0 & x_{p 4}(k)
\end{array}\right]^{\prime}\right\} \\
& \text { if }\left[x_{p}(k) \in\left\{\left[\begin{array}{lll}
1 & 0 & 0
\end{array}\right]^{\prime}\right\}\right] \wedge\left[p_{2}\right] \\
& x_{p}(k) \\
& \text { if }\left[u(k)=\left\{\left[\begin{array}{llll}
0 & 0 & 0 & 0 *
\end{array}\right]^{\prime}\right\}\right] \\
& \left\{\left[x_{p 1}(k) x_{p 2}(k) x_{p 3}(k) *\right]^{\prime}\right\}
\end{aligned}
$$

otherwise

$$
y(k):=g_{p}\left(x_{p}(k), w(k)\right):=\left[x_{p}(k)^{\prime} w(k)\right]^{\prime}
$$

と与えられる。ただし，記述の簡単のため， $u(k) \in \mathbb{B}^{5} \backslash$ $\left\{\left[\begin{array}{llll}0 & 0 & * * *\end{array}\right]^{\prime},\left[\begin{array}{llll}1 & 0 & 1 & 1\end{array}\right]^{\prime},\left[\begin{array}{llll}0 & 1 & 1 & 1\end{array}\right]^{\prime}\right\}$ および $u(k) \in\left\{\left[\begin{array}{lll}0 & 0 *\end{array}\right.\right.$

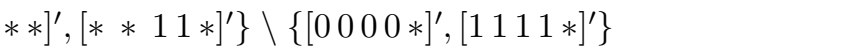

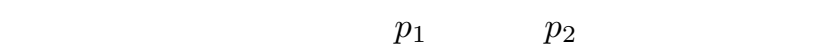
こで， $p_{1}$ および $p_{2}$ は，乥れ光れタンク内の液面が上昇す ることおよび下降することを意味する。また,$w \in \mathbb{B}$ は， 起動スイッチの状態を変化させる外部入力である。

〈4.2〉 ラダー図 図 7 の制御対象に対して, 制御仕 樣を以下のように与える。

（1）初期状態では，すべてのバルブか閉じられており， タンクには液体はないものとする。また , ミキサ $u_{5}$ はオフである。

（2）起動スイッチが押されたらバルブ $u_{1}$ を開き，セ ンサ $x_{2}$ が 1 になるまでバルブ $u_{1}$ から液体 $\mathrm{A}$ が注 入される。 （a ）液体 $\mathrm{A}$ が注入され， $x_{2}$ がはじめて 1 にな るとミキサ $u_{5}$ が稼働する。

（b）液体 $\mathrm{A}$ の $\mathrm{pH}$ をセンサ $x_{4}$ により検出し，規 定の值でないならば，バルブ $u_{2}$ を開き，液 体 B を注入する。

（3）液体 B を注入して，センサ $x_{3}$ が 1 になったらバ ルブ $u_{2}$ を閉じて液体 B の注入をやめ, バルブ $u_{4}$ を 開いて液体を $x_{2}$ の位置まで排出する。乥して再び バルブ $u_{4}$ を閉じ ,(2b) の処理を行う。

（4）液体の $\mathrm{pH}$ が規定の值を満たしている（中和完了） ならば , バルブ $u_{2}$ を閉じ , 液体をバルブ $u_{3}$ から排 出する。产の後, 液面が下降し, センサ $x_{1}$ が 0 と なったらバルブ $u_{3}$ を閉じ，( 1 ）の過程に戻る。

上記の制御仕樣を満たすラダー图を図 8 に示す。ここ で, $\Sigma_{X}=\left\{x_{1}, x_{2}, x_{3}, x_{4}, x_{5}\right\}, \Sigma_{U}=\left\{u_{1}, u_{2}, u_{3}, u_{4}, u_{5}\right\}$, $\Sigma_{T}=\Sigma_{M}=\emptyset$ である。

〈4. 3〉 閉ループ系の状態空間と状態遷移の構成 ラ ダ一図の状態空間 $X_{c}$ を求めるため, $Y=X_{p} \times \mathbb{B}$ とする。 また，起動スイッチに関する仮定として， $w(k)=1(k \geq 0)$

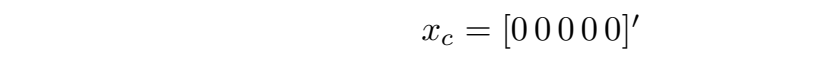
とき，Algorithm 1 によって，ラダー図の状態空間

$$
\begin{aligned}
& X_{c}=\left\{\left[\begin{array}{lllll}
0 & 0 & 0 & 0 & 0
\end{array}\right]^{\prime},\left[\begin{array}{lllll}
0 & 0 & 0 & 0 & 1
\end{array}\right]^{\prime},\left[\begin{array}{lllll}
0 & 0 & 0 & 1 & 1
\end{array}\right]^{\prime},\left[\begin{array}{lllll}
0 & 0 & 1 & 0 & 1
\end{array}\right]^{\prime},\right. \\
& \left.\left[\begin{array}{lllll}
0 & 1 & 0 & 0 & 1
\end{array}\right]^{\prime},\left[\begin{array}{lllll}
1 & 0 & 0 & 0 & 0
\end{array}\right]^{\prime},\left[\begin{array}{lllll}
1 & 0 & 0 & 0 & 1
\end{array}\right]^{\prime}\right\}
\end{aligned}
$$

を得る。また，制御対象の初期状態を $x_{p}=\left[\begin{array}{llll}0 & 0 & 0 & 0\end{array}\right]^{\prime}$ とし， Algorithm 2 によって, 閉ループ系の状態空間

$$
\begin{aligned}
& X=\left\{\begin{array}{llllllllll}
0 & 0 & 0 & 0 & \mid & 0 & 0 & 0 & 0 & 0
\end{array}\right]^{\prime},\left[\begin{array}{llllllllll}
0 & 0 & 0 & 0 & 1 & 0 & 0 & 0 & 0
\end{array}\right]^{\prime},
\end{aligned}
$$

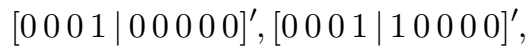

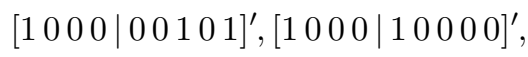

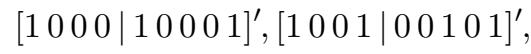

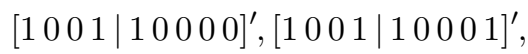

$$
\begin{aligned}
& \text { [1 } \left.1 \begin{array}{lllllllll} 
& 0 & 0 & 0 & 0 & 0 & 1 & 1
\end{array}\right]^{\prime},\left[\begin{array}{lllllllll}
1 & 1 & 0 & 0 & 0 & 0 & 1 & 0 & 1
\end{array}\right]^{\prime} \text {, }
\end{aligned}
$$

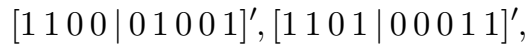

$$
\begin{aligned}
& \text { [1 } \left.1 \begin{array}{llllllll} 
& 0 & 1 & 0 & 0 & 1 & 0 & 1
\end{array}\right]^{\prime},\left[\begin{array}{lllllllll}
1 & 1 & 1 & 0 & 0 & 0 & 0 & 1 & 1
\end{array}\right]^{\prime} \text {, } \\
& \text { [1 } \left.111|| 000011]^{\prime}\right\}
\end{aligned}
$$

を得る。ただし，(19) 式において，表記の見やすさのた め, $\left[x_{p}^{\prime} x_{c}\right]^{\prime}$ を $\left[x_{p}^{\prime} \mid x_{c}\right]^{\prime}$ としている。また，また，閉ルー プ系の状態遷移图を図 9 に示す。図 9 において, 円は状

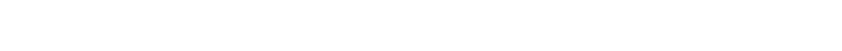
デルの状態 $x_{p}=\left[\begin{array}{llll}x_{1} & x_{2} & x_{3} & x_{4}\end{array}\right]$ およびラダー図の状態 $x_{c}=\left[\begin{array}{lllll}u_{1} & u_{2} & u_{3} & u_{4} & u_{5}\end{array}\right]$ を表すものとする。

図 9 より，制御対象の状態 $x_{p}=\left[\begin{array}{llll}1 & 0 & 0 & 1\end{array}\right]^{\prime}$ ，すなわち， 図 7 の中和タンクシステムにおいて , センサ $x_{1} \quad\left(x_{2}\right.$ およ び $\left.x_{3}\right)$ がオン (オフ) で, $x_{4}$ がオン，すなわち規定の $\mathrm{pH}$ 值を満足 (中和完了) している状態に対して, 動作指令と 


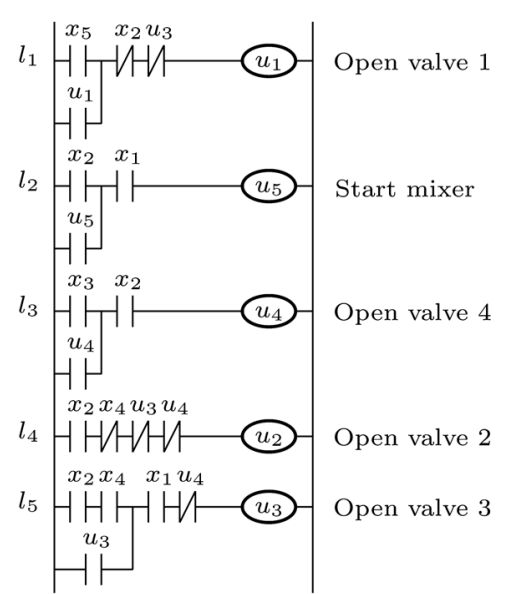

図 8 中和タンクシステムに対するラダー図

Fig. 8. Ladder diagram for neutralization tank system.

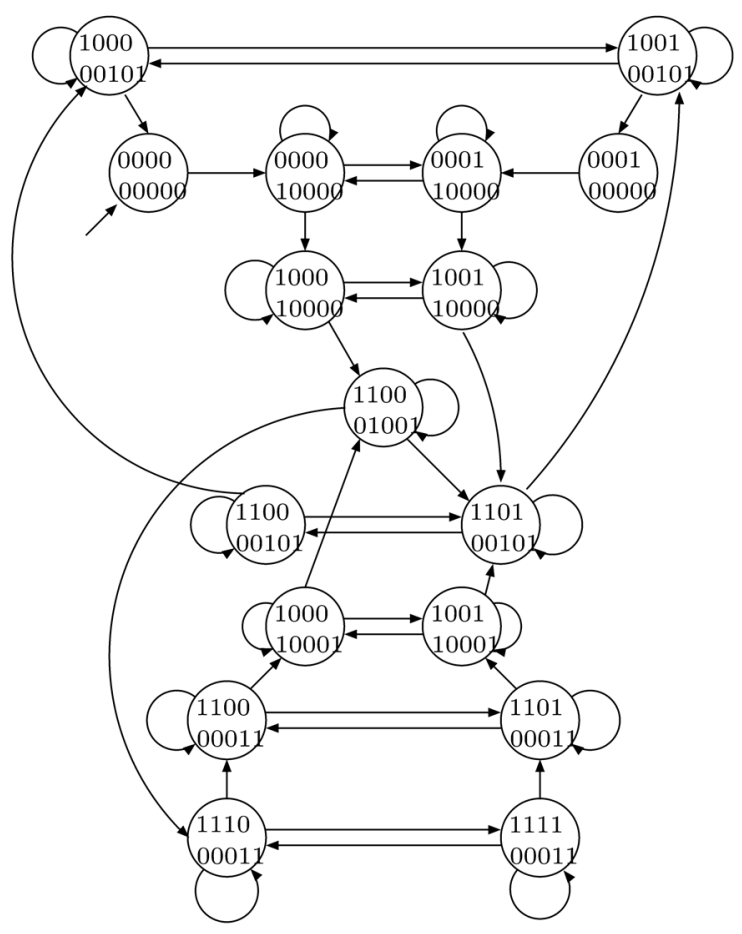

図 9 閉ループ系の状態遷移図

Fig. 9. State transition of closed loop.

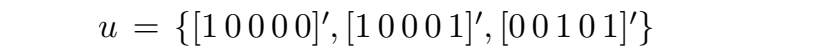
が分かる。したがって, 乥れら以外の状態か観測されたと きは，定義 1 から故障状態である。

〈4 4〉故障診断 ここでは, 図 9 に示される閉ルー プ系の状態空間および状態遷移に対し，故障箇所の特定の 手順について述べる。

故障状態の例として，以下に 3 つの具体例を示す。

1 つめの例として， $x=\left[\begin{array}{lllllllll}0 & 0 & 0 & 0 & 1 & 0 & 0 & 0 & 0\end{array}\right]^{\prime}$ を観測した

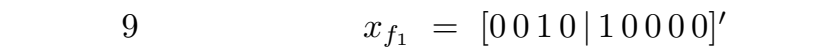
状態として検出されたとする。このときの状況を図 10 に示す。このとき， $x_{f_{1}}$ の故障箇所を特定するため， $x_{f_{1}}$

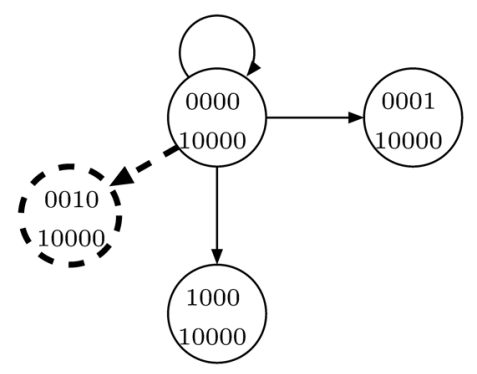

図 10 故障状態の例 1 (点線は存在しない状態 および状態遷移)

Fig. 10. Example of fault state \#1 (dased line: nonexsitent state and transition).

の直前の状態 $x$ から遷移可能な状態集合は, $X^{N}(x)=$

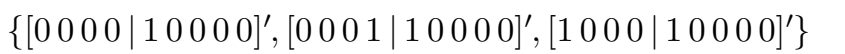
して得られる。ここで $(15)$ 式より $F\left(x, x_{f_{1}}\right)$ は，

$$
\begin{aligned}
F_{p}\left(x, x_{f_{1}}\right)= & {\left[\begin{array}{lll}
x^{N_{1}} \oplus x_{f_{1}} & x^{N_{2}} \oplus x_{f_{1}} & x^{N_{3}} \oplus x_{f_{1}}
\end{array}\right] } \\
= & {\left[\begin{array}{lll}
0 \oplus 0 & 0 \oplus 0 & 1 \oplus 0 \\
0 \oplus 0 & 0 \oplus 0 & 0 \oplus 0 \\
0 \oplus 1 & 0 \oplus 1 & 0 \oplus 1 \\
0 \oplus 0 & 1 \oplus 0 & 0 \oplus 0
\end{array}\right] } \\
= & {\left[\begin{array}{lll}
0 & 0 & 1 \\
0 & 0 & 0 \\
1 & 1 & 1 \\
0 & 1 & 0
\end{array}\right] \ldots \ldots \ldots \ldots \ldots(20) }
\end{aligned}
$$

となる。(20) 式において,$i=3$ のとき $\forall j\left(f_{i j}=1\right)$ が成 立することから，センサ $x_{3}$ の故障が特定される。

2 つめの例として,$x=\left[\begin{array}{lllllllll}0 & 0 & 0 & 0 & 1 & 0 & 0 & 0 & 0\end{array}\right]^{\prime}$ を観測した 後, $x_{f_{2}}=\left[\begin{array}{lllllllll}0 & 1 & 0 & 0 & 0 & 0 & 0 & 0\end{array}\right]^{\prime}$ が観測されたとする。 $x_{f_{2}}$ は図 9 に示す状態遷移図に存在しない状態であること から 1 つめの例と同樣，故障状態である。このときの 状況を图 11 に示す。 1 つめの例と同樣に， $X^{N}(x)=$

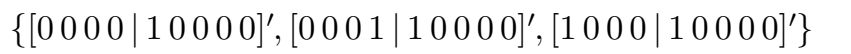
得られ，

$$
F_{p}\left(x, x_{f_{2}}\right)=\left[\begin{array}{lll}
0 & 0 & 1 \\
1 & 1 & 1 \\
1 & 1 & 1 \\
0 & 1 & 0
\end{array}\right]
$$

となる。ここで, $i=2,3$ において $\forall j\left(f_{i j}=1\right)$ が成立す ることから， $x_{2}$ および $x_{3}$ の故障箇所が特定される。

3 つめの例として,$x=\left[\begin{array}{lllllllll}1 & 0 & 0 & 0 & 1 & 0 & 0 & 0 & 0\end{array}\right]^{\prime}$ を観測し

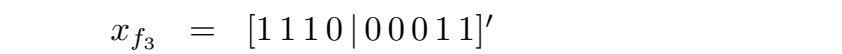
この状態 $\tilde{x}_{f_{3}}$ は図 9 に示す状態遷移図に存在しない遷 移により生起した状態であることから，故障状態であ る。このときの状況を図 12 に示す。同樣に $X^{N}(x)=$

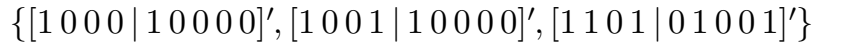
得られ， 


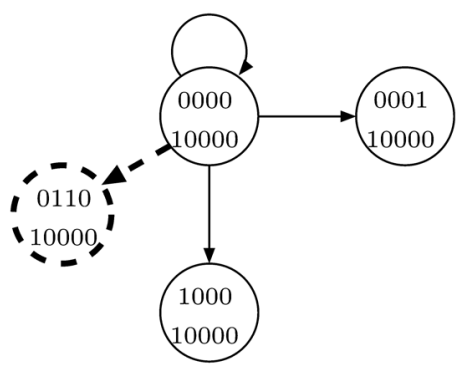

図 11 故障状態の例 2 (点線は存在しない状態 および状態遷移)

Fig. 11. Example of fault state \#2 (dased line: nonexsitent state and transition).

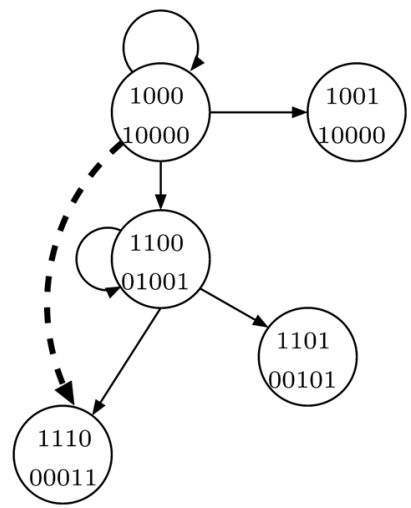

図 12 故障状態の例 3 (点線は存在しない状態 遷移)

Fig. 12. Example of fault state \#3 (dased line: nonexsitent transition).

$$
F_{p}\left(x, x_{f_{3}}\right)=\left[\begin{array}{lll}
0 & 0 & 0 \\
1 & 1 & 0 \\
1 & 1 & 1 \\
0 & 1 & 0
\end{array}\right]
$$

となる。ここで, $i=3$ において $\forall j\left(f_{i j}=1\right)$ が成立する ことから， $x_{3}$ の故障が特定される。

仮定 2 の（2）より，以下ではプラントモデルの状態 , た とえばリミットセンサなどの破損・動作不良などに起因する なお，ここでは仮定 2 の（2）より，プラントモデルの状 態のみの故障を想定したが , 仮定 2 の ( 2) を削除し，(15) 式における $\left(1: n_{p}\right)$ および定理 2 における $\left(i=1, \ldots, n_{p}\right)$ を谷れ光れ $\left(1: n_{p}+n_{c}\right)$ および $\left(i=1, \ldots, n_{p}+n_{c}\right)$ と変 更することで, プラントモデルと制御器の閉ループ系に故 障が生じる場合に対しても適用することができる。

\section{5. おわりに}

本稿では, PLC としてラダー図によって制御されるシー ケンス制御系を例にとり，制御対象のモデル化が完全では ないということを等価的に非決定性を有するシステムであ るとみなし，状態遷移を集合值関数としてモデル化した。 乥して，与えられたラダー図とプラントモデルに対して閉 ループ系を構成し，状態空間および状態遷移を与えるアル
ゴリズムを提案した。次に，得られる閉ループ系は生起し 得る状態および状態遷移のみを生成することから，状態遷 移図から逸脱した状態および状態遷移を観測したときの状 態を故障状態とし , 故障特定手法を提案した。最後に，具体 例として中和タンクシステムに提案手法を適用し , 閉ルー プ系の状態遷移図を構成し, 故障特定手法の手順について 述べた。以上より，提案手法がロジックコントローラによっ て制御されるシステムの故障診断へ有効であることを明ら かにした。

今後の課題として , 制御器の故障を考慮したときの故障 診断への適用, 制御対象と制御器のクラスを拡張した場合 の考察, 得られた閉ループ系の状態数に対する定量的な評 価などが挙げられる。

(平成 17 年 3 月 14 日受付, 平成 17 年 7 月 1 日再受付)

$$
\text { 文献 }
$$

(1) P.J.G. Ramadge and W.M. Wonham: "The control of discrete event systems", Proceedings of the IEEE, Vol.77, No.1, pp.81-98 (1989)

(2) S. Eilenberg: Automata, Languages, and Machines, Vol.A, Academic Press (1974)

( 3 ) L.S. Homen de Mello and A.C. Sanderson: "AND/OR graph representation of assembly plans", IEEE Trans. on Robotics and Automation, Vol.6, No.2, pp.180-199 (1990)

(4) P. Freedman: "Time, Petri nets, and robotics", IEEE Trans. on Robotics and Automation, Vol.7, No.4, pp.417-433 (1991)

( 5 ) J.C.M. Baeten and W.P. Weijland: "Process algebra", Cambridge Tracts in Theoretical Computer Science Vol.18, Cambridge University Press (1990)

(6) C.A.R. Hoare: "Communicating Sequential Processes", Prentice-Hall (1985)

( 7 ) K.T. Seow: "Temporal logic formulation of assembly sequence properties", IEEE International Conference on Robotics and Automation, pp.1208-1213 (1992)

(8) K.T. Seow: "A temporal framework for assembly sequence representation and analysis", IEEE Trans. on Robotics and Automation, Vol.10, No.2, pp.220-229 (1994)

(9) C.M. Ozveren and A.S. Willsky: "Observability of Discrete Event Dynamical Systems", IEEE Trans. on Automatic Cotrol, Vol.35, No.7, pp.797-806 (1990)

(10) M. Sampath and K. Sinnamohideen: "Failure Diagnosis Using Discrete-Event Models", IEEE Trans. on Control Systems Technology, Vol.4, No.2, pp.105-124 (1995)

(11) M. Sampath and K. Sinnamohideen: "Diagnosability of Discrete-Event Systems", IEEE Trans. on Automatic Cotrol, Vol.40, No.9, pp.1555-1575 (1995)

(12) Y. Fujimoto: "Design of Discrete Time Polynomial Nonlinear Systems and Its Application to Sequential Control", T. IEE Japan, Vol.122-D, No.9, pp.918-927, (2002-9) (in Japanese) 藤本康孝 :「離散時間多項式非線形システムの制御系設計法とシー ケンス制御への応用」, 電学論 D , 122, 9, pp.918-927 (2002-9)

(13) H. Ito and T. Nanri: "Fault Diagnosis and Operation Continuation of Sequential Control System Using Petri Net", T. SICE, Vol.33, No.9, pp.914-922 (1997-9) (in Japanese) 伊藤宏隆・南里孝行:「ペトリネットによりシーケンス制御システムの 故障診断と運転継続」, 計測自動制御学会論文集 , 33, 9, pp.914-922 (1997-9)

(14) S.H. Zad, R.H. Kwong, and W.M. Wonham: "Fault diagnosis in finite-state automata and timed discrete-event systems", Topics in Control and its Appl.: A Tribute to Edward J. Davison, D.E. Miller and L. Qiu, Eds. Springer-Verlag, pp.81-105 (1999)

(15) S.H. Zad, R.H. Kwong, and W.M. Wonham: "Fault Diagnosis in Timed Discrete-Event Systems", in Proc. 38th IEEE Conference on Decision and Control, pp.1756-1761 (1999)

(16) J.S. Ostroff: Temporal Logic for Real-Time Systems. Research Studies Press Ltd. 
(17) D.M. Gabbay and H.J. Ohlbach: Temporal Logic. LNAI 827 Springer-Verlag.

(18) R. Kumar and V.K. Grag: Modeling and Control of Logical Discrete Event Systems. Kluwer Academic Publishers.

(19) T. Zanma, T. Suzuki, A. Inaba, and S. Okuma: "Transformation Algorithm from Ladder Diagram to SFC Using Temporal Logic", T. IEE Japan, Vol.117-D, No.12, pp.1471-1479 (1997-12) (in Japanese)

残間忠直・鈴木達也・稲葉昭夫・大熊 繁 :「時間論理によるラダー 図から $\mathrm{SFC}$ への变換法」, 電学論 D , 117, 12, pp.1471-1479 (1997-12)

(20) A. Falcione and B.H. Krogh: "Design Recovery for Relay Ladder Logic", IEEE Control Systems Magazine, April, pp.90-98 (1993)

（21）小倉久和 : 情報の基礎離散数学, 近代科学社 (1999)

残 間 忠 直 (正員) 1972 年生。2000 年 3 月 名古屋大学大

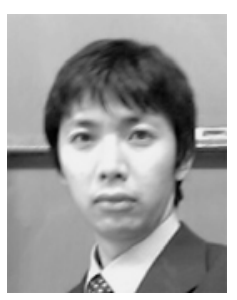
学院博士課程後期課程電気工学専攻修了。同年 4 月 三重大学工学部電気工学科助手。現在に至る。 博士 (工学)。離散事象システム, シーケンス制 御 , ハイブリッド動的システムとの炎の応用 , 混 合論理動的システム論に基づくモーションコント ロール・システム同定および電動機制御・パワー エレクトロニクス回路への応用に関する研究に従 事。計測自動制御学会, システム/制御/情報学会, IEEE 各会員。
宮 林

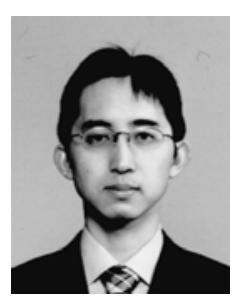

司 (非会員) 1979 年生。 2003 年 3 月 三重大学工 学部電気電子工学科卒業。同年 4 月 三重大学大 学院工学研究科電気電子工学専攻入学。2005 年 3 月 三重大学大学院工学研究科電気電子工学専攻 修了。同年 4 月 (株) 京三製作所に入社。現在に 至る。在学中は, 離散事象システムの故障診断に 関する研究に従事。

石 田 宗秋 (正員) 1952 年生。1980 年 3 月 名古屋大学大

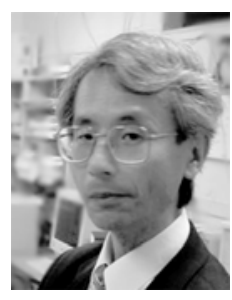
学院工学研究科電気工学及び電子工学専攻博士課 程後期課程修了。同年 4 月 同大学工学部電気工 学科助手, 1987 年 6 月 三重大学工学部電気工学 科助教授, 1996 年 10 月 同大学工学部電気工学 科教授 , 現在に至る。博士 (工学)。主として, 電 動機制御，パワーエレクトロニクスに関する研究 に従事。1993 年および 2001 年電気学会論文賞， 1999 年電気学会著作賞, 2002 年計測自動制御学会論文賞, 2005 年 溶接学会論文賞受賞, IEEE, パワーエレクトロニクス学会, 計测自 動制御学会, 日本機械学会, 溶接学会各会員。 